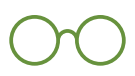

¿MATRIMONIO

HETEROSEXUAL?

¿MATRIMONIO IGUALITARIO?

ASPECTOS PSICOLÓGICOS

\section{DEL COMPORTAMIENTO}

\section{HUMANO}

Daniel Fernando Gómez Tamayo

Universidad Cooperativa de Colombia

Sede Bogotá

\title{
NOTA LEGAL
}

El presente documento de trabajo ha sido incluido dentro de nuestro repositorio institucional como Apropiación social de conocimiento por solicitud del autor, con fines informativos, educativos o académicos. Asimismo, los argumentos, datos y análisis incluidos en el texto son responsabilidad absoluta del autor y no representan la opinión del Fondo Editorial o de la Universidad.

\section{DISCLAIMER}

This coursework paper has been uploaded to our institutional repository as Social Appropriation of Knowledge due to the request of the author. This document should be used for informational, educational or academic purposes only. Arguments, data and analysis included in this document represent authors' opinion not the Press or the University.

Apropiación social del conocimiento Generación de contenidos impresos https://repository.ucc.edu.co/handle/20.500.12494/7375 N. ${ }^{0} 21$, noviembre de 2020 doi: https://doi.org/10.16925/gclc.14 


\section{ACERCA DEL AUTOR}

Daniel Fernando Gómez Tamayo, Doctor en Derecho Canónico por la Pontificia Universidad Javeriana. Coordinador del Área de Humanidades, Facultad de Derecho, Universidad Cooperativa de Colombia, sede Bogotá. Correo electrónico: daniel.gomezt@campusucc.edu.co

\section{CÓMO CITAR ESTE DOCUMENTO}

Gómez-Tamayo, D. F. (2020). ¿Matrimonio heterosexual? ¿Matrimonio igualitario? Aspectos psicológicos del comportamiento humano (Generación de contenido impreso n. ${ }^{\circ} 21$ ). Ediciones Universidad Cooperativa de Colombia. Doi: https://doi.org/10.16925/gclc.14

Este documento puede ser consultado, descargado o reproducido desde nuestro repositorio institucional (http://repository. ucc.edu.co/handle/20.500.12494/7369) para uso de sus contenidos, bajo la licencia de Creative Commons Reconocimiento-NoComercial-SinObraDerivada 4.0 Internacional. http:// creativecommons.org/licenses/by-nc-nd/4.0/

\section{(c) $(1) \Theta$}




\section{1 ¿MATRIMONIO HETEROSEXUAL? ¿MATRIMONIO IGUALITARIO? ASPECTOS PSICOLÓGICOS DEL
COMPORTAMIENTO HUMANO}

Daniel Fernando Gómez Tamayo

\section{Resumen}

Esta lectura crítica se pregunta en torno al matrimonio heterosexual y al matrimonio igualitario. Se hace un análisis jurisprudencial de los derechos fundamentales de los niños, atendiendo a una familia patriarcal o a una familia matriarcal y se dan algunas reflexiones con respecto a las sentencias C-577 de 2011 y C-071 de 2015 desde las investigaciones forenses internacionales, y la violencia doméstica, en particular, con el análisis de la Ley 599 de 2000 y la Ley 1257 de 2008.

Palabras clave: análisis jurisprudencial, feminismo, matrimonio heterosexual, matrimonio igualitario. 


\section{TABLA DE CONTENIDO}

Políticas PÚBlicas incluyentes $\quad 5$

$\begin{array}{ll}\text { El MATRIMONIO HETEROSEXUAL Y LA FAMILIA NUCLEAR } & 7\end{array}$

La Convención de Belém do Pará y la violencia doméstica 8

Aspectos PSicológicos Del COMPoRtAMiento humano 10

¿Familia patriarcal? ¿Familia matriarcal? Derecho y género 14

SERVIDORES PÚblicos: ¿CONFLICTO DE GÉNERO?, ¿CONFLICTO DE INTERÉs? 14

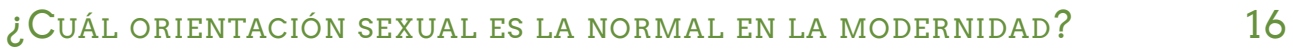

¿QUIÉN ES LA AUTORIDAD COMPETENTE PARA DEFINIRLA?

Aportes del derecho CANónico: Aproximación DESDE LA GenÉtica 17

El ETHOS RELIGIOSO Y LOS OBITER DICTUM 21

¿EL TERCER GÉNERo? LOS FACTORES AMBIENTALES 22

El Debate JURÍdico De los DeREChos 23

$\begin{array}{ll}\text { CONCLUSIONES } & 24\end{array}$

$\begin{array}{ll}\text { REFERENCIAS } & 25\end{array}$ 


\section{POLÍTICAS PÚBLICAS}

\section{INCLUYENTES}

Para algunos sectores progresistas de la opinión pública, la decisión de la Corte Constitucional de Colombia con respecto al matrimonio igualitario fue una conquista del pensamiento liberal, de los "framers, radicales y masones", porque la elección de la pareja debe ser una decisión libre de cada persona y más aún cuando estamos en un estado democrático plural, diverso e incluyente (Lawrence, 1999, p. 364).

Para algunos juristas resulta claro que las lesbianas, las personas bisexuales e incluso los homosexuales ya no necesitan contraer matrimonio católico porque la Corte Constitucional de Colombia permitió el matrimonio civil e igualitario. Y aunque la decisión de los jueces constitucionales ha de ser respetable, lo importante es que sea una decisión libre, informada y que se haga efectiva cuando las persona sean mayores de edad. El matrimonio no es la ceremonia ni tampoco es la luna de miel: cada persona puede tener sus propias motivaciones para contraer matrimonio civil o católico. Eso es ciertamente respetable. Por ejemplo, las personas creen que el matrimonio es para tener relaciones íntimas, tal como lo disfrutaron durante el noviazgo; otros contraen matrimonio para tener familia y dar un hogar a sus hijos, o para estar acompañadas durante la vejez hasta que llegue la enfermedad terminal y la muerte natural, como lo señala la Ley 1733 de 2014. Sin embargo, es evidente que las personas pueden tener relaciones íntimas sin necesidad de casarse, que son los contrayentes los que tienen la obligación de bendecir a su familia, y que la soledad es parte consustancial de la vida. Para el sector más conservador de la sociedad, el debate académico en la Corte Constitucional se centra en establecer si las parejas LGBTI tienen el derecho a tener familia, de modo similar a como lo pueden tener las parejas heterosexuales. Lo cierto es que desde la técnica argumentativa avanzada se infiere que ni las parejas heterosexuales ni tampoco las parejas homosexuales tienen el derecho a tener prole o descendencia, por cuanto por evidencias científicas existen personas con orientación heterosexual y también homosexual que son estériles.

En efecto, según la epistemología médica, existen mujeres que buscan el embarazo, pero no pueden lograrlo por algunos problemas de fertilidad, como en los casos de diagnóstico clínico de ovarios poliquísticos y de endometriosis. Igualmente, hay otra malformación genética que se produce en algunas mujeres y que se caracteriza por la falta de desarrollo del útero y que se denomina el síndrome de Mayer-Rokitansky-KüsterHauser. Finalmente, también existe otra malformación genética que se puede producir en algunas mujeres: la ausencia del desarrollo de las trompas de Falopio, a lo que se conoce como agenesia mulleriana.

Por otro lado, es importante advertir que también existen casos de infertilidad en los hombres bien sea porque los espermatozoides tienen poca movilidad y no pueden traspasar los ácidos de la vagina para fertilizar el ovocito, o bien, porque tienen astenozoospermia o escasez de espermatozoides; o finalmente cuando se diagnostica varicocele bilateral subclínico (Vásquez, 2014). Por ende, no se puede confundir el derecho que puede ser exigible procesalmente ante un juez, con una simple expectativa o con una contingencia biológica que puede hacerlo posible o no.

Ahora bien, el simple hecho de que un hombre y una mujer contraigan matrimonio civil o católico no significa necesariamente que deba presumirse que las personas que toman la decisión de casarse tengan una orientación heterosexual, porque esa presunción se puede desvirtuar a través de los medios de prueba que permite la Ley 1564 de 2012, al igual que 
con evidencias obtenidas constitucionalmente y legalmente desde la Jurisdicción Canónica que es internacional, pues existen muchos indicios que nos muestran que las personas que no son heterosexuales, es decir, que tienen una orientación sexual diversa, también han contraído matrimonio civil y católico desde hace muchos años. Otra cosa muy distinta es que las personas no tengan conocimiento de la orientación sexual de la pareja que eligieron durante el noviazgo porque forma parte de la intimidad de cada persona, en tanto en cuanto que una cosa es la aptitud de fertilizar, y otra muy distinta es la orientación o preferencia sexual.

De hecho, la infidelidad de las personas que contraen matrimonio civil o católico no es solamente heterosexual, porque la infidelidad de hombres y de las mujeres puede ser con personas del mismo género sexual.

Aunque la Corte Constitucional permite la adopción de menores por parte de parejas del mismo sexo, en virtud de la ejecutoria de las Sentencias C-577 de 2011 y C-071 de 2015, es claro que los jueces constitucionales debieron exigir alguna entrevista estructurada previa a la pareja adoptante, independientemente de la orientación sexual, para descartar, por ejemplo, posibles parafilias y exigir la trazabilidad por parte del Instituto Colombiano de Bienestar Familiar (ICBF) respecto a los derechos del adoptado. Por otro lado, en el caso concreto de las parejas homosexuales, resulta claro que ellos pueden tener familia por medio de la reproducción asistida mediante la fertilización heteróloga, esto es, mediante la adquisición de un ovocito que proviene de una mujer donante, o en un banco de células a través de la maternidad subrogada o el alquiler de vientres.

El problema jurídico en este último caso sería la discusión de la titularidad de los derechos con respecto al material genético donado para fertilizar el embrión humano, pues hasta el momento, y según los avances de la ciencia médica, no se ha logrado la implantación exitosa de una matriz en el hombre transgénero ni en un transexual.

Con respecto al matrimonio igualitario, ya no es necesario que las mujeres utilicen a los hombres heterosexuales y los demanden por cuota alimentaria después del divorcio, porque las personas LGBTI pueden ir a un banco de células reproductivas y escoger el espermatozoide que prefieran según el genotipo y fenotipo, y como el donante es un anónimo, entonces la demanda por cuota alimentaria no se puede radicar ni admitir ante los jueces de reparto, por carencia de identificación clara de los sujetos procesales.

Pareciera que los medios de comunicación de radio, prensa y televisión se enfocaran en publicar únicamente, por ejemplo, los casos de pedofilia de los clérigos y los casos donde las mujeres resultan ser las víctimas de maltrato por parte de los hombres. Eso me parece respetable. No obstante, ¿qué sucede si los casos de pedofilia de los clérigos se confunden con la orientación bisexual u homosexual? Desde la psicológica clínica y el derecho canónico resulta claro que no se pueden confundir las parafilias con la orientación sexual, pero resulta evidente que existen casos de pedofilia y acoso homosexual y heterosexual.

Ahora bien, si la conducta sexual entre personas del mismo género es tolerada socialmente hasta cierto umbral, porque jurisprudencialmente las personas LGBTI tienen derechos constitucionales en virtud del activismo judicial, al igual que los heterosexuales, entonces conviene preguntarse: ¿qué sucede en el caso inadmisible del ilícito de la pedofilia y de la pornografía infantil? Por otro lado, con respecto al control que ejercen los medios de comunicación masivos sobre la información judicial que se publica en radio, prensa y 
televisión, las preguntas, desde la perspectiva de los televidentes y radioescuchas, son: ¿por qué razón no se publican los casos de maltrato de madres a los niños?, ¿por qué razón no se publican los casos de bullying, maltrato verbal y psicológico por motivos estéticos, de coeficiente intelectual o posición socioeconómica, que se presentan a diario en los colegios femeninos entre las niñas?, ¿por qué razón no se publican los casos de acoso sexual entre adolescentes del género femenino que se dan entre los catorce y los diecisiete años? (Bieber et al., 1988, p. 207).

\section{EL MATRIMONIO}

\section{HETEROSEXUAL Y LA FAMILIA NUCLEAR}

Los activistas de los derechos humanos de las personas LGBTI creen que el matrimonio heterosexual surge como una imposición heteronormativa impuesta por la Iglesia Católica; sin embargo, resulta evidente que el matrimonio se conoció, en la etapa primitiva de la historia de la humanidad, como algo simple de ley natural: la unión marital de hecho entre un hombre con una mujer para el bien de los cónyuges y de los hijos. Lo cierto, y con respecto al origen de la diversidad de razas, es que inicialmente esta unión se dio por la atracción entre personas heterosexuales y por una simple costumbre de los seres humanos de amarse con fines de reproducción (Uribe Uribe, 2001, p. 213).

Desde la perspectiva de la teoría de evolución de las especies de Charles Darwin, es claro que en la etapa primitiva los únicos instrumentos que se inventaron fueron herramientas para la caza, la pesca y la cocina, pero en esa época ni el hombre de Neandertal, ni el Cro-magnon, ni el Homo sapiens, ni el Homo australopithecus, ni el Homo habilis tenían tanta imaginación como para inventarse juguetes sexuales que satisficieran a las mujeres. De hecho, los robóticos, es decir, los bienes muebles y fungibles, son un invento de los siglos XX O XXI.

A través de investigaciones se evidenció, por ejemplo, que "en la familia punalúa —una tribu primitiva en Norteamérica- se permitió el intercambio de parejas (relaciones Swinger) y también el incesto" (Morgan, 1972, pp. 373, 536). Después las relaciones evolucionaron hasta la implementación de una relación de monogamia. En la actualidad, en pleno siglo xxI, ciertamente hemos regresado a la etapa primitiva de la humanidad, porque existen casos de madres que obligan a sus hijas menores de edad a tener relaciones íntimas con su padrastro para que este no se vaya con otra.

Para Aristóteles (2000, La política, I, 2: 1252a), es necesario que se emparejen los seres que no pueden subsistir; entre los animales, el macho con la hembra, con vistas a la generación, lo cual quiere decir que se presume la unión heterosexual en la naturaleza. En el Medioevo, fue Tomás de Aquino quien estableció: "Pertenece al orden natural todo aquello que la naturaleza enseñó a todos los animales (reproducción heterosexual)" (Aquino, 2001, St II-II, q. 154 a.2); pero, a diferencia de los animales, en las personas debe ser de modo natural, unitivo y estable, según lo manda la ley natural.

De hecho, el matrimonio heterosexual no lo hacen los clérigos, ni el juez, ni tampoco el notario; es más, el matrimonio civil lo celebran las personas, porque son los seres humanos los que eligen a su compañero sentimental en la etapa del noviazgo para compartir la vida y los bienes.

Por esta razón, el matrimonio heterosexual surge de una costumbre universal, y no como una imposición heteronormativa de alguna autoridad pública. Aún más, con fundamento en los artículos 5, 43 y 44 de la Constitución 
Política de 1991, se infiere que todo niño tiene el derecho a tener una madre biológica y un padre biológico. Es esta una simple costumbre praeter legem y secundum legem que está en consonancia con el Tratado de Derechos del Niño del Fondo de las Naciones Unidas para la Infancia (UNICEF).

Por lógica constitucional, resulta claro que la Corte Suprema de Justicia exige la prueba genética de ADN cuando existe duda razonable con respecto a la identificación filial de la madre biológica o del padre biológico, puesto que los niños que se encuentran en el vientre materno son poseedores del derecho a tener una familia nuclear (Solarte Rodríguez, 2010).

Entonces, ¿cómo se puede llegar a esa cifra matemática de 7000 millones de personas que justifiquen el crecimiento demográfico de la población, si la inclinación heterosexual no fuese natural e innata? Las estadísticas a lo largo de la historia demuestran que el fenómeno de la sobrepoblación da cuenta en gran medida que los actos reproductivos de la naturaleza humana, e incluso que los actos instintivos que se dan entre personas del género masculino con personas del género femenino, son naturales e innatos (Kunzi, 2011).

Desde el punto de vista científico, es claro que el espermatozoide, la célula que produce el hombre, siempre busca al ovocito, una célula producida por el ovario de la mujer. De suerte que, si el efecto lo demuestra, también lo es su causa, que es la atracción heterosexual de las personas; por ende, la bisexualidad no es genética, ni hereditaria, ni mucho menos innata.

Los expertos en ciencia políticas de Estados Unidos sostienen que el movimiento LGBTI surgió a finales de los años sesenta en la ciudad de Nueva York como reacción a la redada policial en el bar Stonewall, pero lo realmente curioso del surgimiento de este movimiento es que se dio en una época donde el consumo de marihuana, cocaína, LCD y otras drogas era la máxima expresión de libertad, y para ello no es sino mirar la época del surgimiento del movimiento hippie en EE.UU. en los años 1969 y 1970 (Lipsitz y Speak, 1993, p. 218).

La pregunta que me surge es: ¿existe alguna relación entre la orientación sexual diversa, el consumo de drogas por vía de inyecciones y el viH? Expertos en genética dicen:

Simon Levay encontró que en la región
cerebral Inah-3 (núcleo intersticial del
hipotálamo anterior) es mayor en las per-
sonas heterosexuales que en aquellas
personas homosexuales. Sin embargo,
para el científico William Byne, las inves-
tigaciones de Simon Levay y Dean Hamer
no son válidas porque las muestras de
tejido nervioso provinieron de pacientes
con (viH/sida). (Barreda, 2001, p. 2).

Lo anterior explica el dimorfismo en el núcleo del hipotálamo intersticial anterior Inah-3; lo cierto es que pueden existir algunos casos, pero no se puede generalizar.

\section{La Convención de Belém DO PARÁ Y LA VIOLENCIA DOMÉSTICA}

Las preguntas que me surgen son: ¿qué origina la violencia intrafamiliar?, ¿por qué razón existen relaciones disfuncionales? A este respecto, "Timothy W. Smith, catedrático de psicología en Universidad de Utah, presentó un estudio ante la Sociedad Psicosomática de Estados Unidos donde concluye que la forma de "interactuar de la pareja era un factor de riesgo cardíaco" (Parker Pope, 2007).

En la mayoría de ocasiones, la violencia doméstica puede estar asociada a problemas asertivos de comunicación de pareja, 
indistintamente de la orientación sexual. En efecto, el dia 14 de octubre de 2007 se publicó un artículo donde se revisan los motivos de discusión de pareja, entre los cuales están: "los hijos (mujeres: 9,7\%; hombres: 5,6\%), tareas del hogar (mujeres: 8,7\%; hombres: 4,2\%), dinero (mujeres: $8,5 \%$; hombres: $6,2 \%$ ) y alcohol (mujeres: 7,2\%; hombres: 4,4\%). Estudiaron a 4000 personas de los géneros masculino y femenino de Framingham, Massachusetts" (Parker Pope, 2007).

Se dice que Benkert, físico húngaro, fue en 1869 el primero en utilizar la palabra gay (Tobin, 1964). No obstante, la pregunta es: ¿cuáles son los motivos concretos de discusión de las parejas LGBTI y que han contraído matrimonio igualitario? Por ejemplo, en otros casos, el maltrato verbal, psicológico y físico infantil puede estar asociado con la orientación sexual diversa o con la preferencia LB de muchas mujeres que han contraído matrimonio civil o católico.

Es común encontrar que algunas personas con preferencias sexuales diversas contraen matrimonio civil y católico por diversos intereses; pero olvidan que sus conflictos no resueltos van a salir a flote durante la convivencia matrimonial, y pueden afectar la estabilidad emocional de los menores de edad. Por ejemplo, ¿pueden las mujeres con dispareunia superar la dificultad de su psiquismo racional y relacional para convivir establemente con un hombre?, ¿por qué razón las mujeres que no son heterosexuales tiene una propensión marginal hacia el maltrato de los niños?, ¿por qué razón existen hombres amanerados, bisexuales y gay?, ¿por qué razón algunos de ellos no desean convivir realmente con una mujer?, ¿por qué razón las mujeres con orientación sexual diversa se van a convivir con su novia después de quedar embarazadas de un hombre?, ¿por qué razón algunas mujeres que planifican son tan inestables endotímicamente durante el matrimonio civil o católico?
Para otros, el debate jurídico de las minorías se enfoca en determinar: ¿cuáles son las libertades civiles que se pueden atribuir por jurisprudencia de la Corte Constitucional a las personas con preferencia u orientación sexual diversa que en el fondo buscan una relación monoparental? En efecto, y desde las políticas públicas de Estado, los Gobiernos dicen oficialmente que no tienen recursos públicos para asumir los costos del sostenimiento de menores abandonados en el ICBF o que están en situación irregular a causa del conflicto armado, y por ello prefieren entregarlos en adopción a parejas monoparentales o diversas; pero lo curioso es que los países sí tienen recursos presupuestales para invertir en armas, hacer la guerra y destruir familias nucleares, desconociendo así los derechos fundamentales de los menores. ¿Por qué el servicio militar es obligatorio si existe la objeción de conciencia?

De la interpretación del Código de la Infancia y la Adolescencia es claro que la Ley 1098 de 2006 permite la adopción de menores por parejas monoparentales; no obstante, la pareja adoptante, e independientemente de su orientación sexual, no puede manipular los sentimientos de los adoptados según sus intereses económicos. Lo cierto es que existen personas con orientación sexual heterosexual y diversa que no necesariamente están interesados en adoptar niños del ICBF.

A este respecto, un estilista famoso opinó el día 24 de julio de 2005 que "no se debe permitir la adopción de menores por estas parejas, porque los menores no sabrían a quién decirle mamá y además no se les puede llamar matrimonio" (Canal Caracol, 2005). Y aunque pueden existir casos de personas heterosexuales agresivas con los niños, la Corte Constitucional colombiana debió formularse los problemas jurídicos sustanciales y los problemas jurídicos procesales. Por ejemplo, desde el punto de vista probatorio, las preguntas son: ¿será que no puede existir violencia intrafamiliar en las 
relaciones monoparentales?, ¿por qué razón las feministas afirman que los hombres son pasivos-agresivos cuando no responden a las agresiones verbales o psicológicas y a veces físicas de las mujeres?

Ahora bien, si la Convención de Belém do Pará prohíbe el maltrato verbal, psicológico y físico de la mujer, incluso cuando son niñas, ¿entonces eso quiere decir que las madres sí pueden maltratar verbal, psicológica y físicamente a los niños porque no existe una convención similar que proteja a los hombres cuando están en la infancia?, ¿por qué razón algunas personas tienen que gritar, cuando, en lugar de ello, podrían dialogar con sus hijos o utilizar técnicas de comunicación más asertiva?

En todo caso, antes de tomar una decisión judicial en políticas públicas de infancia y adolescencia con respecto a la adopción de menores por parejas diversas, deberían reunir los medios de prueba razonables. La Corte Constitucional de Colombia estableció en la Sentencia SU-080 de 2020 que la mujer maltratada por su cónyuge tiene el derecho al incidente de reparación. Esa medida garantista es muy razonable y pertinente con las mujeres víctimas de violencia por parte de hombres agresivos y machistas. Sin embargo, ¿el incidente reparatorio se puede hacer extensivo a las víctimas de maltrato verbal, psicológico y físico en otras circunstancias?, ¿qué sucede si el maltrato verbal, psicológico y físico no es causado por culpa de los hombres?, ¿qué sucede si las víctimas son los hombres, los niños y las niñas? Pues según la interpretación del artículo 102 de la Ley 906 de 2004, en todo caso la víctima de un delito, independientemente de la orientación sexual, puede tener el derecho al incidente de reparación integral.

En el imaginario colectivo se piensa que las mujeres son generalmente tiernas $\mathrm{y}$ románticas, y que los hombres son fuertes, agresivos e infieles. No obstante, ¿qué sucede si en algunos casos la mujer resulta ser la victimaria de los hechos tipificados en la Ley 1761 de 2015?, ¿por qué razón existen mujeres autoritarias, frías y agresivas con los niños?, ¿qué sucede si la violencia de género se presenta entre el mismo género femenino?, ¿qué opinan de los casos de bullying por razones estéticas, la acepción de personas por razones socioeconómicas y de marca de ropa en los colegios femeninos?

Ahora bien, si el derecho para los positivistas son las pruebas, y aunque todos los hombres decentes y pacíficos nos oponemos al maltrato verbal, psicológico y físico de la mujer. Desde el punto de vista médico: algunas mujeres sufren física y psicológicamente con el cáncer, o cuando les aplican el desfribilador para reanimarlas de un posible infarto cardiaco.

\section{Aspectos PSICOLÓGICOS DEL COMPORTAMIENTO HUMANO}

Desde la antropología y la psicología, el debate en la Asociación Americana de Psicología (APA) se centra en determinar si la conducta sexual diversa es sana desde el punto de vista fisiológico y psicológico, y para ello es necesario revisar el estado del arte del conocimiento y las políticas públicas sobre los derechos de las minorías y las tendencias culturales sobre sexualidad, y determinar las posibles causas que explican el comportamiento entre personas del mismo género sexual.

En muchos casos, la alteración del comportamiento social de las personas puede obedecer a estresores circunstanciales, tales como los problemas de movilidad, el estrés, el mal clima laboral, los problemas financieros, la inflación y el costo de vida. Y, como se advirtió previamente, la violencia intrafamiliar no está asociada necesariamente a la convivencia heterosexual per se. En otros casos clínicos, la 
violencia doméstica puede ser originada por cambios de personalidad que se adquieren por el contexto ambiental de las personas, sin distingos de género, raza, sexo, religión y cultura; en otras situaciones, puede estar relacionada con factores y variables que nada tienen que ver con la genética, ni con la preferencia sexual heterosexual, o con trastornos de personalidad previstos en DSM-V.

Desde las políticas públicas, los gobiernos están trabajando en programas de inclusión social de las personas LGBTI; en algunos casos, en la resocialización, y en otros, en la resiliencia de las personas con orientación sexual diversa. A este respecto, se hace necesario estudiar la argumentación de las Sentencias C-577 de 2011 y C-071 de 2015, de la Corte Constitucional colombiana, a la luz de las ciencias antropológicas y por vía inductiva.

Los activistas de derechos humanos de la población diversa LGBTI sostienen que las personas con orientación sexual diversa provienen de matrimonios heterosexuales y de familias católicas. No obstante, con fundamento en los artículos 5, 6 y 15 de la Constitución Política de 1991, las preguntas desde el punto de vista probatorio son: ¿cómo se puede argumentar esta tesis sin violar el derecho de la privacidad personal y familiar de las personas, si son civiles y particulares?, ¿cómo se puede argumentar esta tesis sin medios de pruebas y evidencias que sean inconstitucionales o ilegales?, ¿qué sucede si los funcionarios públicos, por tratar de probar que los homosexuales provienen de parejas heterosexuales, terminan violando los derechos de los LGBTI?

Según la línea de investigación del derecho canónico consistente en el análisis de pruebas documentales, y de las investigaciones forenses fruto del estudio de los medios de prueba que provienen de Fiscalía, Medicina Legal, toxicología, historias clínicas, pruebas periciales, test de psicología Machover, test de Rorschach,
16 PF, declaraciones, confesiones y testimonios internacionales, se deduce que esa tesis de los activistas no es correcta porque muchas personas LGBTI han contraído matrimonio civil y también católico, ocasionando problemas de salud reproductiva y configurando relaciones disfuncionales. En efecto, son las personas las responsables de elegir a su pareja en la etapa del noviazgo, y no existen reglas en la interpretación del comportamiento humano desde la óptica del psicoanálisis o la psicología clínica, porque pueden existir excepciones a la regla general, pues así como los médicos y los psiquiatras pueden diagnosticar enfermedades médicas o trastornos de personalidad en personas heterosexuales, igualmente lo pueden hacer en personas LGBTI.

El feminismo agrupa mujeres de orientación sexual diversa, también mujeres heterosexuales e incluso hombres que buscan la equidad de género y la conquista de los derechos constitucionales para las mujeres. Eso es respetable.

No obstante, existen algunas ecuaciones jurídicas que son importantes de analizar desde el derecho de familia, porque los niños necesitan de familias naturales o jurídicas que tengan una comunicación asertiva y afectiva de los padres biológicos o adoptantes, y que además respeten los derechos previstos en el artículo 44 de la Constitución Política de 1991 y en el tratado Internacional de la UNICEF.

Si, por ejemplo, en el noviazgo una mujer elige a un hombre como esposo que consume drogas, y como consecuencia de su adicción tanto ella como los hijos son víctimas de violencia doméstica, la pregunta es: ¿esta situación será culpa de quién?, ¿qué sucede si una mujer en el noviazgo elige un hombre que consume licor de forma crónica, y durante la convivencia ella es víctima de una relación disfuncional por los cambios de comportamiento agresivos de él?, ¿qué sucede si el hombre tiene una inestabilidad endotímica $\mathrm{o}$ un trastorno 
bipolar? La pregunta es: ¿esta situación será culpa de quién? Si un hombre escoge a una mujer que en realidad quiere ser mamá, pero que realmente no quiere convivir con él, y después del embarazo ella lo demanda por una cuota alimentaria, ¿esta situación será culpa de quién?

Si una mujer contrae matrimonio con un hombre bisexual o gay, y él le trasmite una infección, o el virus del papiloma humano por la vagina, ¿esta situación será culpa de quién?, ¿qué pasa si la mujer con los exámenes de citología previa sale bien, y se comprueba que el hombre tuvo relaciones previas con una mujer o con un hombre por el colon?, ¿qué sucede si un hombre durante el noviazgo escoge a una mujer bisexual como esposa, y el varón contrayente o los hijos viven una relación caracterizada por altibajos y discusiones frecuentes?

En este mismo contexto, ¿qué ocurre si una esposa resulta serle infiel a su esposo con otra mujer durante la convivencia matrimonial?, ¿esta situación será culpa de quién? Si un hombre escoge una mujer con orientación sexual diversa, y esta maltrata verbal, psicológica y físicamente a los niños porque en el fondo de su corazón prefería una niña, ¿qué implica esto?, ¿qué sucede si posteriormente ella lo denuncia ante las autoridades de Policía, en la Comisaría de Familia o en la Fiscalía por un presunto caso de acoso sexual, porque el matrimonio no les da ningún derecho a los hombre para abrazarlas o acariciar su cuerpo sin el consentimiento de ellas?, ¿esta situación será culpa de quién?, ¿por qué razón algunas mujeres divinas y hermosas no son heterosexuales?

Desde la epistemología médica se sabe que existen riesgos en la salud reproductiva de contraer el cáncer de cuello uterino, o el cáncer de colon o el virus del papiloma humano si no se da una estabilidad y una buena asepsia en las relaciones sexuales, pues así como hay hombres que tienen fantasías íntimas con varias mujeres o con damas de compañía, igualmente existen mujeres que desarrollan fantasías con varios hombres (Medlineplus, 2020). Por evidencias canónicas, se sabe que algunas mujeres han contraído el virus del papiloma humano por causa del aborto o el legrado en hospitales públicos o clínicas privadas, o también por la trasmisión por parte de hombres con orientación sexual diversa a las mujeres por la vagina, pues muchos de los hombres bisexuales o gais pueden preferir las relaciones por el colon. Lo cierto es que el diagnóstico del virus del papiloma humano en la mujer se puede hacer con un informe anatomopatológico, O LLETZ, bajo anestesia general, es decir, mediante impresión diagnóstica NIC-HPH, y la biopsia de citología que muestra que existe una lesión escamosa intraepitelial (Tribunal Eclesiástico Regional de Bogotá, 2014).

Se dice que los primeros brotes de sífilis se detectaron en Francia en el siglo XVI; sin embargo, y fruto del diálogo con bacteriólogas, ginecólogas y científicas de los laboratorios, comentaban que ellas no entendían esto: ¿por qué razón en los exámenes de citología de algunas mujeres se encuentran bacterias que provienen del colon? Lo cierto es que no se entiende esto: ¿por qué razón los hombres tienen relaciones íntimas con mujeres promiscuas, si ellas pueden ser culpables de la trasmisión de infecciones urinarias, de bacterias y hongos por la mala asepsia?

Ahora bien, ¿los movimientos feministas plantean la opción de una madre sustituta para garantizar los derechos de la infancia, porque según estadísticas del DANE, según el grupo etario y género del 2020, en Colombia se evidencian muchos casos de cáncer de mama, próstata y muchos otros de enfermedades cardiorrespiratorias? (Tabla 1). El problema es que esta estadística se refiere a los casos reportados en algunas ciudades de Colombia. 
Tabla 1.

Defunciones no fetales ocurridas y reportadas por la fuente, entre el 1 de enero y el 31 de julio de 2020

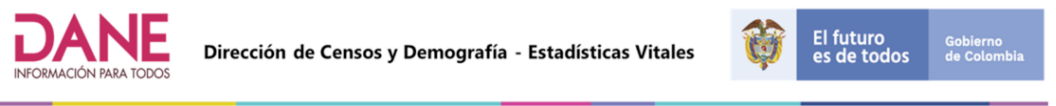

Defunciones por grupos de edad y sexo, según departamento, municipio de residencia y grupos de causas de defunción (Lista de causas agrupadas 6/67 CIE-10 de OPS)

Año corrido 2020 preliminar - (Defunciones no fetales ocurridas y reportadas por la fuente, entre el 1 de enero y el 31 de julio de 2020)

\begin{tabular}{lcccc} 
& Bogotá & Popayan & Barranquilla & Monteria \\
\hline 206 Tumor maligno de la mama de la mujer & 337 & 52 & 138 & 50 \\
207 Tumor maligno del cuello del útero & 132 & 37 & 69 & 41 \\
208 Tumor maligno del cuerpo del útero & 74 & 5 & 8 & 4 \\
209 Tumor maligno del útero, ( otra) & 29 & 6 & 13 & 5 \\
210 Tumor maligno de la próstata & 298 & 49 & 142 & 72 \\
\hline
\end{tabular}

Fuente: Departamento Administrativo Nacional de Estadística (DANE, 2020).

Por otro lado, aunque es cierto que existen casos de maltrato de hombres a las mujeres, conviene preguntarse: ¿qué sucede si se verifica en una entrevista estructurada que esos hombres fueron víctimas de maltrato previo o antecedente por sus propias madres biológicas? En realidad, no necesariamente los progenitores biológicos son personas responsables para asumir el rol materno o el rol paterno. Por regla general, las mujeres heterosexuales que contraen matrimonio civil o católico no se sienten acosadas cuando un hombre quiere relaciones íntimas, incluso cuando son infieles con otros hombres. Sin embargo, sí es muy común encontrar casos de mujeres con orientación sexual diversa que contrajeron matrimonio civil o católico y que exigen del consentimiento previo para cada relación íntima, porque, de lo contrario, el hombre corre el riesgo de ser denunciado por acoso sexual, pues el matrimonio no les da el derecho a los hombres para invadir su cuerpo.
¿Por qué razón las mujeres son más propensas de enfermarse de trastornos endocrinos a causa del aborto y los anticonceptivos como el dietilestilbestrol?, ¿qué incidencia tiene el consumo de drogas psicotrópicas en los casos de violencia doméstica?, ¿qué incidencia tiene el consumo crónico de licor con el trastorno bipolar y en el cambio de comportamientos de la persona?, ¿por qué razón existe mayor riesgo de que las mujeres contraigan el virus del papiloma HPV por el legrado, por relaciones íntimas con hombres bisexuales o gais, o por relaciones íntimas entre mujeres?, ¿por qué razón algunas adolescentes han sufrido los efectos secundarios de la vacuna contra el virus del papiloma humano? Lo cierto es que la medicina es casuística, y las mujeres se están enfermando de depresión y trastorno bipolar por el aborto, el consumo de anticonceptivos y también por el alcohol (Motta, 2005). 


\section{¿FAMILIA PATRIARCAL? \\ ¿FAMILIA MATRIARCAL? DERECHO Y GÉNERO}

Ciertamente, desde la época de Roma a las mujeres se les discriminó por su género; los pater familias no les permitían administrar sus bienes y su patrimonio. En Colombia, solo hasta el Plebiscito de 1957 se les permitió ejercer sus derechos civiles y políticos, como en el caso del derecho al voto. Muchas juristas norteamericanas han promovido la defensa de los derechos de las mujeres, y han criticado los roles de la mujer y del hombre en la sociedad contemporánea, la cultura machista y la familia patriarcal (West, 2000).

Sin embargo, en la sociedad actual existen muchos matriarcados, y más aún con el incremento de separaciones de hecho y divorcios, puesto que muchas madres son cabeza de hogar y viven solamente con sus hijos. Y, aunque la Corte Constitucional de Colombia describe diferentes modelos de familia, en mi opinión, la familia patriarcal tiene su origen con los actores del conflicto y los militares, porque a los machistas les gusta ver a sus esposas haciendo las tareas de la casa, mientras ellos salen de misión y les son infieles con mujeres o con hombres.

La familia patriarcal y machista tiene su origen con la oficial, según el Decreto 1002 de 2019 y la Sentencia C-315 de 2002, puesto que las mujeres prefieren casarse con oficiales porque viven solas con sus hijos en casas fiscales, sin pagar gastos por servicios ni tampoco impuestos; además, reciben subsidios por cada hijo y les incrementan el salario en un 30\%, y sobre todo porque a sus esposos los trasladan de lugar de residencia según las necesidades de la Fuerza Militares.

Desde la tesis de las servidumbres voluntarias del psicoanalista francés Jacques Marie Émile Lacan, existen muchos padres machistas y sobreprotectores de las mujeres que no permiten que sus hijas se independicen de su hogar cuando tienen autonomía financiera, porque según los obiter dictum religiosos la única forma de emanciparse de la casa es a través de una propuesta matrimonial, y esto también afecta la libertad interna de elección de la mujer.

La Corte Constitucional de Colombia, por medio de la Sentencia T-449 de 2008, ordenó a los tribunales eclesiásticos entregar fotocopias de los expedientes en virtud del derecho de petición a las partes; por ende, no se incurre en el delito de discriminación por razones de género previsto en la Ley 599 de 2000, ni tampoco en violencia y discriminación contra las mujeres prevista en la Ley 1257 de 2008, porque no hay reserva forense internacional.

¿Por qué razón las mujeres modernas quieren ser mamás y no desean convivir con un hombre? (Acevedo, 2005, p. 122). En realidad, hay algunas mujeres heterosexuales que se divorcian de su esposo con justa causa y solo desean vivir con sus hijos porque así encuentran la felicidad y la paz. Otros expertos opinan que quizás a las mujeres modernas solamente les interesa adquirir el statu quo de madres cabeza de hogar por los privilegios económicos que otorga la ley, según se desprende de la lectura del artículo 3 de la Ley 1232 de 2008, y el privilegio laboral de la estabilidad reforzada, según se infiere de la Sentencia T-320 de 2016 y la ratio decidendi constante de la jurisprudencia de la Corte Constitucional de Colombia.

\section{SERVIDORES PÚBLICOS: ¿CONFLICTO DE GÉNERO?, ¿CONFLICTO DE INTERÉS?}

En materia de políticas públicas de equidad de género, en Colombia se implantó la Ley 1010 de 2006, que describe y reglamenta las prácticas 
que se consideran por la ley como acoso laboral, maltrato, persecución, discriminación, entorpecimiento, inequidad y desprotección laboral. Y aunque a veces se puede tipificar el acoso laboral con el acoso sexual, ambos no pueden confundirse. Otra cosa muy distinta es el acoso sexual y las injurias de hecho que están reguladas en la Ley 599 de 2000. Es importante que se sancione el feminicidio en la Ley 1761 de 2015, pero, ¿por qué razón no judicializan los casos de acoso sexual entre mujeres si hay muchos casos y ocurren en la adolescencia entre los 14 y los 17 años y bajo efectos del alcohol o el éxtasis? ¡Qué tal la pasividad y la complicidad de los forenses y de los servidores públicos! ¡Qué tal la ecuación del maltrato infantil, no hay derecho! En todo caso, la Sala de Casación Penal de la Corte Suprema de Justicia ha distinguido entre las injurias de hecho (Corte Suprema de Justicia, 2016), el acoso laboral (Ley 1010 de 2006), el acoso sexual y el abuso sexual (Ley 1257 de 2008).

Ahora bien, se dice que la Fiscalía monitorea las redes sociales y toma evidencias de audio y video desde la tecnología del búnker sin el consentimiento previo de los particulares, a través del sistema y los televisores, violando así la privacidad del domicilio de las personas particulares y de las familias que han contraído matrimonio civil o católico, con el pretexto de proteger a las mujeres y también a los niños del maltrato verbal, psicológico y físico causado por algunos hombres.

Sin embargo, ¿qué sucede si las fiscales entran en conflicto de género?, ¿por qué razón las fiscales no se declaran impedidas cuando existe conflicto de género con un hombre que es víctima de injuria o calumnia?, ¿qué ocurre si las personas vigiladas por los servidores públicos son personas con orientación sexual diversa?, ¿qué sucede si los hechos de maltrato suceden por el ejemplo en un periodo de tiempo determinado del ciclo reproductivo de la mujer?, ¿qué sucede cuando identifican que las madres son las culpables? Por ello, se dice, con razón, que los medios masivos de comunicación y los servidores públicos que controlan las tecnologías de la información y las comunicaciones (TIC) pueden ser sesgados en sus investigaciones, porque incurren en actos de discriminación inversa de los niños y de los hombres.

Si constitucionalmente existe la presunción de la buena fe prevista para los particulares sin discriminación por razones de género, ¿por qué razón la custodia de los hijos se la suelen asignar generalmente a las mujeres, si el incumplimiento de las obligaciones e incluso la infidelidad no solamente se presenta por parte de algunos hombres? Y aunque pueden existir divorcios con justa causa, algunos expertos en derecho de familia se preguntan: ¿cuántos serán los divorcios que buscan simplemente la obtención de un fallo económico adjudicativo de cuota alimentaria y también conyugal? Algunos hombres y mujeres solo quieren gozar de los derechos, pero no desean asumir obligaciones con sus cónyuges ni con los niños. En efecto, muchas personas tienen la costumbre de separarse o divorciarse en algunos casos sin justa causa y sin tener en cuenta el interés superior de la infancia (Elster, 1999, p. 108).

Lo que no se entiende es: ¿por qué razón las mujeres tienen la costumbre de demandar al hombre por cuota alimentaria, si muchas de ellas también son infieles durante el matrimonio con otros hombres o con amigas íntimas?, ¿por qué razón los jueces de familia en Colombia, Europa, Canadá y Estados Unidos siempre otorgan la custodia a las madres, si en algunos casos los hombres también pueden asumir la responsabilidad? En este sentido, el artículo 44 de la Constitución Política de Colombia de 1991 establece que, en caso de conflicto o intersección entre las libertades de las mujeres y los derechos de los niños, es claro que prevalecen los derechos de la infancia. 


\section{¿CuÁl orientación}

\section{SEXUAL ES LA NORMAL EN LA MODERNIDAD? ¿QUIÉN ES LA \\ AUTORIDAD COMPETENTE PARA DEFINIRLA?}

Desde el punto de vista de la democracia participativa e incluyente, es claro que las decisiones se toman por mayorías: no obstante, ¿qué sucede si los alcohólicos anónimos se asocian y solicitan la eliminación del alcoholismo crónico del DSM-V, porque son muy buenas personas, aparte de que el alcohol lo consumen tanto hombres como mujeres? Además, el licor es un producto consumible que se evacúa del cuerpo antes de las 24 horas del cuerpo porque es hidrosoluble, y finalmente este es un producto lícito producido por las licoreras departamentales del país. Lo cierto, y respetando las personas que sufren de delirios o de alucinaciones por efectos de los narcóticos, es que el alcoholismo no se transmite genéticamente de padres a hijos por el gen "whiskey", porque desde la genética este gen no existe.

La Ley 1696 de 2013 sanciona la conducción bajo el influjo del alcohol o de sustancias psicoactivas. Lo primero que hay que advertir es que los licores tienen diferentes grados de alcohol, y que los niveles de concentración de este en la sangre dependen de otras variables (p. e., el modo de consumo, o si se trata de un consumo habitual o frecuente), pues existen unos grados que oscilan entre el nivel 0 y el nivel 3. Lo segundo por considerar, es que los efectos de las sustancias psicoactivas no se pueden comparar con los efectos del alcohol, pues las drogas afectan directamente el consciente. Aunque existen casos registrados de agresividad relacionados por el consumo de drogas o sustancias psicotrópicas, otra cosa sucede con el consumo de alcohol, porque en algunos casos se pueden generar un trastorno bipolar, y en otros, haber un componente de agresividad.

Los derechos se predican de la primera infancia, y no de una preferencia sexual en particular; lo debatible es determinar si algunas personas con orientación sexual diversa fueron víctimas de acoso sexual por victimarios del mismo género sexual; en todo caso, y para algunos de los expertos, se debe reunir evidencias de ADN del acosador. Sin embargo, lo debatible para otros forenses es: ¿cómo se prueba el nivel hormonal en el acosador si este puede variar antes y después de la relación ilícita? Ahora bien, con respecto al acoso sexual, se pueden analizar las Sentencias T-239 de 2018 y T-652 de 2016 de la Corte Constitucional; algunos juristas se preguntan si algunos de ellos fueron inducidos bajo efectos de alguna droga ilícita que es liposoluble, pues esta se queda adherida al tejido adiposo del cuerpo.

Otros especialistas opinan que el debate de los LGBTI se centra en si ellos o ellas nacen o se hacen; lo cierto es que desde la ciencia moderna los genetistas no han encontrado todavía el gen "gay" en la decodificación del mapa del genoma humano. Desde la epistemología médica se establece que el género sexual se define genéticamente por la secuenciación del mapa del genoma humano de cada persona, y esto supone la identificación molecular de los cromosomas. Otra cosa muy distinta es la orientación sexual, que es un problema epistemológico de la psicología clínica y que en algunos casos puede relacionarse con la preferencia sexual y con factores adaptativos ambientales. Según psicólogos y canonistas, "los problemas de agresividad, infidelidad y alcoholismo ocupan el primer rango en el estudio clínico de la persona que es neurótica" (Alarcón, 2005).

En el tribunal de apelaciones de Kentucky, en el caso Stevenson vs. Stevenson de 1980, con base en el criterio de un psicólogo, se dijo 
que "la menor de edad podía correr peligro en su salud física, mental, psicoafectiva, si una madre lesbiana no respeta la integridad física, psicológica y sexual de los menores de edad, o si no se comportan discretamente frente a su hija menor, por esta razón la custodia fue trasladada al hombre divorciado" (Brigham, 1984, p. 162). En efecto, la patria potestad se puede trasladar a otra familia (pareja heterosexual idónea) cuando la anterior familia no le garantiza al menor un mínimo de condiciones dignas para que puede desarrollarse integralmente. En este sentido, la jurisprudencia de la Corte Constitucional colombiana, concretamente en el precedente de la Sentencia T-290 de 1995, señala: "En el caso que nos ocupa, la menor fue alejada del actor".

\section{Aportes Del DeRECHO}

\section{CANÓNICO: APROXIMACIÓN DESDE LA GENÉTICA}

Según los datos que ofrece la ciencia hoy en día, "la sexualidad se determina genéticamente desde el mismo momento de la concepción y se desarrolla a partir de la semana 12-13), esto es, desde la fase de la embriogénesis. Desde las primeras etapas de la vida (infancia) esta inclinación se comienza a exteriorizar como algo natural e innato, aunque hoy por hoy respetuosamente algunos no lo acepten" (Discovery Communications, 2005).

Por investigaciones canónicas que están fundamentadas en la clínica del caso de procesos de nulidad matrimonial a nivel internacional y procesos reservados ante la Santa Sede de Benedicto XVI, es decir, por investigaciones que resultan del análisis de historias clínicas, de los dictámenes de Medicina Legal de Colombia, reportes de policía judicial y expedientes de Comisarías de Familia, pruebas de Fiscalía, entrevistas estructuradas (anamnesis) y test psicológicos de personalidad, la pregunta que nos podemos plantear es la siguiente: ¿los homosexuales nacen o se hacen?

Algunos creyeron que el comportamiento homosexual podía tener alguna causa genética, como Dean Hamer y otros. No obstante, el genetista español Nicolás de la Barreda desmintió esta tesis; aún más, en un estudio de George Rice y George Ebers se registraron familias con más de un miembro homosexual, referidas a más de 400 genealogías, y concluyeron que no existe ningún soporte experimental que demuestre la idea de que la homosexualidad en la persona humana se encuentre asociada a marcadores cromosómicos en la región Xq28 (Barreda, 2001, p. 3).

Sin embargo, la comunidad científica no ha dado credibilidad a esta tesis, pues lo cierto es que los científicos no han encontrado todavía el "gen gay" respectivo en los cromosomas XY del género masculino, ni tampoco en los cromosomas xx del género femenino, pues la orientación sexual es un tema psicológico, y no genético.

Aún más, el comportamiento bisexual entre personas del mismo género es mutable y se puede cambiar según la teoría de la reorientación de "Karen Horney, HS Sullivan, el neurólogo francés Marcel Eck y los expertos en ciencias antropológicas neoyorkinos Charles Socarides y Lawrence Hatterer" (Van Den Aardweg, 2005).

Es más, según la ciencia médica, es claro que la homosexualidad tampoco se transmite genéticamente de una generación a otra, como en 1981 lo sostuvo erróneamente el psicólogo Robert Epstein, en Harvard, con su hipótesis del "continuum" (Epstein, 2007, pp. 55-60), en tanto en cuanto que los descendientes de los homosexuales no necesariamente heredan esa orientación sexual, precisamente porque no existe el gen gay. Los framers, los masones, los radicales y los oficiales fueron en un principio 
excluyentes dela participación dela mujeren las decisiones políticas y democráticas, y por eso, con razón, se decía que sufrían de "misoginia, y en otros casos de homosexualidad" (Van Den Aardweg, 2005, p. 65).

De hecho, las evidencias científicas nos muestran que muchas de las personas homosexuales se hacen por factores ambientales o sociales, y no por causas genéticas. Por ejemplo, si una niña observa que su padre llega borracho a la casa y maltrata a su madre y a sus hijos, ¿eso justifica que una adolescente heterosexual cambie su orientación sexual?, ¿quién eligió al padre de esta niña?, ¿esta situación será culpa de quién?

Desde la concepción existen diferencias genéticas, físicas, fisiológicas y psicológicas sustanciales entre el hombre y la mujer. Los nuevos movimientos sociales y culturales han luchado por el rescate de los derechos de las minorías sexuales, ¿pero hoy por hoy se discute en los estrados judiciales si las personas diversas deben adoptar menores? Desde el punto de vista constitucional y legal, el hombre, así como la mujer, son iguales en derechos y en obligaciones, pero no se puede llegar al absurdo de afirmar que en la naturaleza humana exista, desde el punto de vista médico, un tercer género sexual.

A este respecto, los científicos sostienen que las personas del género masculino se identifican con cromosomas XY, mientras que las personas del género femenino se identifican con los cromosomas xx. En los hombres, el sistema reproductivo (sistema de Wolf) produce espermatozoides cuyas células pueden vivir hasta 24 horas aproximadamente; mientras que el sistema reproductivo en las personas del género femenino (sistema de Müller) produce óvulos que descienden de los ovarios por las trompas de Falopio, y si estas células no se fertilizan, se eliminan.
El científico Gerald L. Klerman, profesor de psiquiatría en la escuela de medicina de Harvard, "pide que los cambios que aparezcan en el DSM-IV, DSM-V sean determinados por la evidencia más que por afirmaciones ideológicas" (Burke, 1998).

Puesto que, para algunos, la decisión de la APA de 1973 y sus reformas son cuestionables porque se perdió la epistemología científica, y ya no se sabe qué es lo normal y qué es lo anormal (Kerbikov, Oseretzki, Popov y Sneshneski, 1976), quizás por la presión social y jurídica de los LGBTI americana, europea y los oficiales. En concepto de psicólogos clínicos, el hombre ejerce el rol paterno y la mujer ejerce el rol materno; no obstante, se pueden presentar problemas en el desarrollo de la infancia o en la adolescencia del menor cuando el hombre o la mujer pretenden asumir ambos roles. Por ejemplo, Lawrence C. Kolb, quien fuera profesor y jefe del Departamento de Psiquiatría del College of Physicians and Surgeons de la Columbia University, "hablaba simplemente de una desviación sexual” (Kolb, 1976, p. 617).

Según investigaciones de expertos de neurociencias de la Universidad de California, se reveló que pruebas hechas por estudiantes estadounidenses, entre 1960 y 1992, mostraron que, en promedio, los varones están más capacitados para matemáticas y materias científicas, peroson máslentos conelmanejo del lenguaje. A las personas del género femenino, por su parte, les va mejor en comprensión y expresión literaria y muestran aptitud superior para sobreponerse a situaciones de estrés prolongado. Sin embargo, el desempeño en las competencias matemáticas no depende del género, sino de las habilidades y aptitudes de cada persona y de la metodología de enseñanza y de aprendizaje.

Lawrence Summers, expresidente de Harvard University, sostuvo en un discurso que las 
diferencias innatas en la construcción del cerebro de personas con cromosomas XY O xx podrían explicar la escasa participación de personas del género femenino en ciencia. No obstante, y en mi opinión, me parece un comentario sexista, pues lo cierto es que existen mujeres odontólogas, bacteriólogas, médicas e ingenieras que son admirables por sus competencias intelectuales y profesionales (Cahill, 2012, pp. 40-47).

Hugo Liaño, jefe del servicio de Neurología del Hospital Puerta de Hierro, de Madrid (España), opinó que los cerebros masculinos y los cerebros femeninos vienen preparados de forma distinta. En mi opinión, esta condición explicaría por qué las diferencias entre el pensamiento de hombre y de la mujer no se dan solo por influencias culturales o cambios hormonales asociados a la pubertad, sino que también podrían explicar el motivo por el cual algunas mujeres son más propensas a cambios del estado de ánimo de acuerdo con el ciclo reproductivo y el consumo de anticonceptivos.

Al revisar el estado del arte en cuanto a las diferencias cerebrales entre hombres y mujeres:

Jill M. Goldstein, de Harvard University, encontró que la corteza frontal (muy importante en algunas funciones cognitivas) es más grande en personas del género femenino que en personas del masculino, lo mismo que en la corteza parietal límbica relacionada con lo emocional, en ellos, la corteza parietal relacionada con la percepción visoespacial es más grande que la femenina.

Sandra Witelson, de McMaster University, descubrió que las personas del género femenino tienen mayor número de neuronas en algunas partes de lóbulo temporal, relacionado con los procesos del lenguaje y la comprensión. Hallazgos similares se reportaron en el lóbulo frontal. Esta diferencia anatómica puede generarse en gran parte por la acción de las hormonas sexuales sobre el cerebro fetal. Estas dirigen la organización y el cableado del cerebro durante el desarrollo. Melissa Hines, de Londres University, y Gerianne M. Alexander, de Texas University, hicieron una investigación con juguetes de monos, comprobaron que los animales masculinos querían juguetes (carros, balones) y los animales que son hembras querían muñecas. Según investigaciones de expertos de neurociencias de la Universidad de California, los monos no están influenciados por la cultura, los científicos creen que puede tratarse de diferencias biológicas innatas, quizá desarrolladas como resultado de presiones selectivas durante la evolución. (Cahill, 2012, pp. 40-47)

El género masculino ciertamente tiende a preferir juguetes en la infancia que puedan ser lanzados, o que promuevan el juego de acción, donde puedan liberar toda la energía física, como en los deportes de despliegue físico en los que se requiere fuerza o resistencia y los videojuegos electrónicos. Podría pensarse que en el caso de las mujeres seleccionan juegos que les permiten utilizar las habilidades y la intuición que un día necesitarán para cuidar a sus hijos, aunque esto no excluye que las mujeres participen en deportes de despliegue físico o jueguen con los carros y los balones.

El psicólogo holandés Gerard J. M. Van Den Aardweg ha estudiado las causas del comportamiento sexual entre personas del mismo género, y señala:

Estas tendencias pueden desarrollarse por un tipo especial de complejo de inferionidad, puesto que por constitución una persona es heterosexual, y en su tesis enfoca la experiencia de la autocompasión como núcleo de la psicología de ellos, resultando 
evidente que un gran número de ellos están insatisfechos con su modo de vida, siendo así que cuando se percatan de su situación, la mayor parte se sienten deprimidos. (Van Den Aardweg, 2005)

Ahora bien, los expertos se preguntan: ¿será que algunas de las personas del género femenino pueden tener fobia a los hombres quizás por haber vivido alguna experiencia traumática con una persona del género masculino, y por eso pueden proyectar su problemática interior en todos los demás?, ¿o será que algunas personas del género femenino pueden tener miedo a lo que implica el embarazo, y por ello buscan para ellas arrogarse derechos filiales que no tienen sobre el nasciturus, cuya patria potestad y custodia corresponde por pruebas de ADN al hombre y a la mujer que aportaron sus células respectivas?

De la simple lectura de los hechos en un tiempo determinado, muchas veces se concluye que el lenguaje corporal no corresponde con el lenguaje verbal que emplean las personas, ya en las investigaciones científicas de la Escuela de Londres de Sumerhill se hablaba de la educación de la infancia y de la adolescencia sin miedo y sin violencia verbal, física y psicológica; es decir, sin ningún tipo de maltrato. Cuando los menores son castigados, existen muchas probabilidades de que, en el futuro, cuando sean madres o padres, respectivamente, sean autoritarios e igualmente maltratadores con su descendencia.

En las fiestas de Halloween existen personas que les gusta disfrazarse de travestis, pero no por ello quiere decir que los disfrazados sean per se personas con preferencias sexuales diversas, o que tengan un trastorno no especificado. Por ejemplo, "es respetable que César Gaviria y la comitiva de la OEA se disfracen en New York", porque eso es una decisión libre en el día de las brujas (Tribunal
Arquidiocesano de Bogotá, Causa de Nulidad Matrimonial Eastman-Rueda).

Bieber et al. (1988) se preguntan "isi el comportamiento sexual entre personas del mismo género se puede presentar cuando las personas pueden tener conflictos (graves) en la relación psicoafectiva con las personas que detentan la patria potestad, o más específicamente con los que buscan una familia monoparental?" (pp. 44). Por otro lado, según Rubén Ardila, Ph.D. en Psicología, desde la teoría freudiana "existiría supuestamente una estructura familiar que produciría personas con esta inclinación sexual: aquella en la cual el que asume el rol (paterno) es una persona pasiva, hostil e indiferente, y la que ejerce el rol (materno) es posesiva, competitiva y calculadora que busca satisfacer un beneficio propio" (Ardila, 2007, p. 70), y que es muy distinto de aquella mujer que es muy competente.

La tesis anterior en el fondo, y con sobrada razón, lo que está postulando y exigiendo para una estructura familiar sana es que el hombre y la mujer estén juntos también en las épocas de crisis, y que cada uno de los que se les confiere la patria potestad esté en capacidad de ejercer el rol como se debe; el hombre al rol paterno y la mujer al rol materno, pues hoy lo que está sucediendo es una verdadera disfunción en los roles por parte de los que detentan la patria potestad, entendiendo por disfunción una falla en el desarrollo normal de la identidad sexual, por culpa de los encargados de educar; tesis que también la confirma Ardila (2007) al afirmar que "el menor de edad aprende a hacerlo por refuerzo, gratificación que recibe por esta conducta" (p. 70). Esta tesis es igualmente desarrollada por Judith $P$. Siegel, de la Universidad de Nueva York, en su obra Lo que los menores aprenden de las relaciones de los que detentan la patria potestad (Van Den Aardweg, 2005). 
Por otro lado, desde el punto de vista jurídico, es claro para los expertos que se deben denunciar penalmente ante las autoridades competentes los casos de "lesión a la integridad física y psíquica, lo mismo que el incesto, el abuso de menores, el proxenetismo, la corrupción y la prostitución infantil", como lo determina perentoriamente la Ley 765 del 2002 y la Ley 1098 de 2006, para evitar así, según el querer de la ley, que otros menores sean víctimas de esos delitos y su relación con las drogas.

Aunque no todos los expertos en ciencias antropológicas comparten las teorías de Freud relativas al origen psicodinámico del comportamiento sexual entre personas del mismo género:

Según Wilhelm Stekel, discípulo de Freud, dijo: "La heterofobia es la consecuencia del miedo al sexo opuesto". Por su parte, E. Bergler, experto austriaco, al investigar sobre este comportamiento sexual, conceptuó: "El impulso sexual hacia personas del mismo género contiene, según él, una especie de autotormento, un sentimiento inconsciente de ser rechazado $\mathrm{y}$, en general, de coleccionar injusticias: situaciones desagradables y experiencias que dan la oportunidad de sufrir". (Van Den Aardweg, 2005)

\section{EL ETHOS RELIGIOSO Y LOS OBITER DICTUM}

Desde el Vaticano se han presentado muchas discusiones, en la interpretación de las Sagradas Escrituras, acerca de los temas de la salud reproductiva y del ethos sexual de los civiles, pero no les conviene analizar los casos de bisexualismo o de homosexualidad en el clero. La Iglesia de Rito Latino, por ejemplo, permite que los clérigos tengan familia si no desean ser patriarcas. Por un lado, la Prelatura
Personal del Opus Dei fomenta el autoritarismo, el clasismo, el machismo y el feminismo con la educación diferenciada, desconociendo los avances de sana antropología y la equidad de género, y muchas veces infundiendo miedo y sentimientos de culpa en los adolescentes heterosexuales que tienen relaciones sexuales naturales prematrimoniales, con los obiter dictum. ¿Por qué razón es más grave lo natural que lo antinatural, si la ley natural es superior a las Sagradas Escrituras?

En el plano constitucional, las personas tienen el derecho a planificar y a utilizar preservativos para preservar la vida, evitar el embarazo no deseado y las enfermedades de transmisión sexual. Para eso existen profesionales en temas de salud reproductiva. Algunos padres de familia conservadores prefieren la educación diferenciada, o que sus hijas tengan amigas para evitar así el noviazgo con los hombres y el embarazo indeseado. Sin embargo, ¿qué van a hacer los padres de familia para evitar el acoso por adolescentes del mismo género femenino en la etapa de los 14 a los 18 años?, ¿qué opinan de los casos de acoso sexual entre niñas, que se han presentado en las 'pijamadas' o en las rumbas bajo efectos de licor o el éxtasis?, ¿qué sucede si una estudiante le levanta la jardinera a la compañera en los colegios femeninos?, ¿qué sucede si una adolescente le da un beso en la boca a la otra niña sin tener el consentimiento previo de la víctima?

En la Iglesia Católica también existen personas con orientación sexual diversa LGBTI que prefieren seguir así, a observar la ley natural; por eso, y a juicio de expertos en temas de derecho de familia, es sugerible que la formación del clero se realice en Instituciones de educación superior, y no en los seminarios, pues no se puede tratar a los religiosos como inmaduros, cada persona debe ser responsable de sus actos. 
Los jesuitas confundieron el derecho canónico (que tenía un enfoque clínico y jurídico) con la teología, pues en la Pontificia Universidad Javeriana discriminaron entre facultades rentables en factor financiero (1.50) y en facultades factor (1.25), siendo inviable realizar investigación cualitativa y cuantitativa en derecho de familia y psicología clínica por vía inductiva con el aval universitario. En efecto, muchos clérigos pretendieron resolver las enfermedades psiquiátricas o los delitos (Fierro, 2014, p. 279), los asuntos de salud reproductiva y la educación sexual con obiter dictum bíblicos y argumentos kantianos, sin tener las pruebas forenses, ni tampoco las evidencias de la psicología clínica para tomar una decisión jurídica de fondo (Escobar y Uribe, 2014, p. 19); es decir, sin tener la evidencia canónica que resulta de lo actuado y de lo probado en los procesos jurídicos.

Muchas mujeres feministas no desean dialogar con los clérigos simplemente porque son hombres, o, por cuanto que son pecadores, pero lo cierto es que los ansiolíticos que necesita una persona con un trastorno de esquizofrenia no se pueden sustituir por palabras poéticas y románticas, así como el ácido valproico que necesita una mujer con trastorno depresivo o bipolar tampoco se puede reemplazar, salvo que tenga la prescripción médica (Hernández Bayona, 2013, p. 325).

\section{¿EL TERCER GÉNERO? LOS \\ FACTORES AMBIENTALES}

Con respecto a este punto, es importante dejar claro que para la epistemología médica no existe un tercer género, sino enfermedades genéticas relacionadas con el desarrollo del aparato reproductivo masculino o femenino.

Según el investigador Neil R. Carlson, de la Univesidad de Massachussets, pueden existir trastornos no especificados: "Si el gen Sry no está, entonces las gónadas indiferenciadas se convierten en ovarios" (Barlow y Durán, 2001).

En el caso del síndrome de Swyer, los científicos establecen que esta enfermedad se suele presentar en las mujeres, y que se debe a mutaciones del gen SRY, y "en estos casos las mujeres no presentan regla y tampoco desarrollan caracteres sexuales secundarios en la pubertad" (Langman, 2004, p. 374). Ahora bien, cuando se presenta, por ejemplo, el síndrome de Klinefelter para el caso del hombre, o el síndrome de Turner para el caso de la mujer, no es que se pueda hablar propiamente de hermafroditismo; puesto que se trata de malformaciones en el aparato reproductor masculino o femenino, en el caso del Klinefelter, las gónadas se forman hacia el interior de la región pélvica y no hacia el exterior, estos pacientes se suelen identificar con un cariotipo de $47 \mathrm{XXY}$, y pueden ser infértiles; en el caso de la mujer se puede caracterizar con una dimensión mayor (protuberancia) de su "órgano de excitación sexual al tamaño estándar" y se identifican con el cariotipo $45 \mathrm{x}$.

En la Sentencia T-477 de 1995, de la Corte Constitucional, se planteó un caso perplejo de "emasculación", pues resulta que un niño recién nacido fue víctima de lesiones corporales de sus gónadas por la acción lesiva de una "mascota ajena"; sin embargo, para otros expertos, el equipo del ICBF y el profesional de salud debieron hacer simplemente la cirugía reconstructiva de su órgano fisiológico para que el menor lograra evacuar los esfínteres, en cuanto que el problema de la genitalidad y la reconstrucción del órgano genital debe ser una decisión de la víctima que debe tomar cuando sea mayor de edad. Para algunos, esta decisión de darle hormonas femeninas e internar al menor en un establecimiento educativo de mujeres fue un error profesional. 
¿Por qué razón algunas personas transgénero o transexuales se suicidan?

\section{EL DEBATE JURÍDICO DE LOS DERECHOS}

Respetando lo que piensan los magistrados en la Sentencia C-75 de 2007 y C-336 de 2008, para un sector de la doctrina los derechos patrimoniales y a la pensión son derechos que se fundamentan en la dignidad del cónyuge, porque esta calidad únicamente se adquiere con el matrimonio natural y el matrimonio civil, dado que la familia únicamente se constituye por la decisión responsable entre un hombre y una mujer (artículo 42 de la Constitución Política de 1991).

A juicio de expertos en temas de familia, hay comportamientos que siguen siendo conflictivos para las personas y que pueden afectar la familia natural a la luz de la ciencia antropológica. No falta quien se pregunte: ¿será que la persona heterofóbica es feliz con su condición? Para Johan Leonard Arndt, experto en ciencias antropológicas de Holanda, "el ser humano que tiene comportamientos sexuales con personas del mismo género puede ser infeliz. En concepto de él, ellos se sienten condenados irremediablemente al sufrimiento; nunca, según el autor, ha visto a una persona que mantiene una relación monoparental feliz; esa es una lucha constante contra el adulto que lo pudo haber inducido a ese tipo de comportamientos" (Van Den Aardweg, 2005).

Sin embargo, ¿podrán las víctimas de esa afectación ejercer acciones civiles por perjuicios morales y afectación a la salud integral? En el 2002 se presentó en Colombia el Proyecto de Ley número 43 de 2002, en el Congreso de la República, por los representantes Carlos Gaviria Díaz y Piedad
Córdoba, con el objetivo de legalizar la unión matrimonial de personas del mismo género, como también se ha hecho en España, Bélgica, Holanda y Canadá; según ellos, para no vulnerar el principio de igualdad y para que no haya discriminación sexual. Según la tesis de Van Den Aardweg (2005), todo depende de la educación de los menores y, en particular, de la relación entre esta y el desarrollo comportamiento

La jurisprudencia de la Corte Constitucional ha tenido diversas posturas al hablar de compañero permanente, pues para algunos jueces esto supone una relación heterosexual, como lo ha dicho la Corte Constitucional colombiana en la Sentencia SU-623 de 2001 y la Sentencia T-349 de 2006, pese a que otros jueces piensen que esto se hace extensivo a las parejas LGBTI, como ocurre en la Sentencia C-029 de 2009. Ahora bien, según el artículo 156 del Código Civil de Colombia, el artículo 10 de la Ley 25 de 1992, la ratio dedicendi de la Sentencia C-246 de 2002 y la Sentencia C-985 de 2010 que regulan el divorcio sanción, la pregunta que surge es: ¿qué sucede con el derecho a la cuota alimentaria que exigen muchas mujeres a los hombres, si ellas son infieles con personas que en el common law son "masseurs"? El problema jurídico no solo es instintivo o sexual; por el contrario, los derechos de los niños se deben fundamentar en el bien mutuo de los cónyuges, la procreación y la educación sana e integral de la descendencia.

En todo caso, no es la pareja la que tiene el derecho a tener una familia, sino, por lógica inversa y según la Sentencia C-814 de 2001, son los infantes y los adolescentes los que tienen derecho a tener una familia nuclear integrada por su padre y su madre, para tener referentes claros y definidos desde el punto de vista del ethos saludable para su normal desarrollo, según se desprende de la lectura de la Convención de los Derechos del Niño de la UNICEF, puesto que por mayoría estadística de los niños es claro que ellos se afectan endotímicamente por las 
discusiones y las separaciones de sus padres biológicos.

La emancipación de los hijos no se puede asociar con los criterios legales de la mayoría de edad (los 18 años), porque también es importante revisar la madurez psicológica y la discreción de juicio. Finalmente, hoy por hoy, está comprobado, desde el punto de vista de los expertos en desarrollo infantil, que no es bueno que los que detentan la patria potestad tengan discusiones cargadas de violencia en palabras, acciones y en los gestos frente a los menores. De hecho, cuando los adultos tengan temas objeto de diferencias y de discusión que deban solucionarse, deben frenar racionalmente sus instintos reactivos y pasionales y proceder a buscar espacios o escenarios privados, e incluso con la ayuda de terceros (profesionales) si es necesario, para la comunicación y solución pacífica de sus diferencias.

\section{Conclusiones}

¿Será que con esta decisión de la corte Constitucional de Colombia con respecto al matrimonio entre personas del mismo género sexual se podrían disminuir exponencialmente los índices de violencia doméstica o de relaciones disfuncionales en los matrimonios civiles o católicos?, ¿se podrían disminuir los casos de maltrato verbal, psicológico y físico en los niños?, ¿los hombres se exponen menos a demandas por cuota alimentaria o denuncias por presuntos casos de acoso?, ¿esta decisión puede contribuir a la reducción de casos de trasmisión del virus del papiloma humano en las mujeres? Lo cierto es que las personas LGBTI, al igual que los heterosexuales, tienen el derecho a la vida, a la salud, a la seguridad social, a un trabajo digno, a un salario justo, a las libertades individuales, a la propiedad privada, etc. Los derechos fundamentales se predican de los niños y no se predican de una pareja que tenga una orientación sexual en particular, porque son los hijos los que tienen el derecho a tener una familia.

Desde la teoría de la evolución de las especies de Charles Darwin, las preguntas que surgen son: ¿por qué razón habría de suponerse que las parejas del mismo género están en mejores condiciones para la adopción de un menor, si por naturaleza biológica no están dotadas para la reproducción humana?, ¿por qué razón habría de ser mejor el modelo de familia "monoparental" en comparación con el modelo de la "familia nuclear"? En realidad, los hijos provienen del amor entre un hombre con una mujer, y los niños sufren por el divorcio y por el desprecio de los progenitores biológicos.

Después de haber realizado el presente estudio investigativo, es importante dejar en claro que toda persona se presume sana, salvo que se desvirtúe lo contrario, pues los médicos, los psiquiatras y los psicólogos clínicos pueden diagnosticar enfermedades médicas o trastornos de personalidad independientemente de la orientación sexual (Stella, 1997).

Desde el derecho civil moderno se debate si las mujeres y los hombres tienen la aptitud cualitativa para desempeñarse como tutores de los menores sin haber tenido procesos de resiliencia o sin cumplir con un umbral probatorio razonable, pues resulta claro que cuando se trata de designar a un curador de los bienes del menor, lo importante es acreditar la responsabilidad en la administración de los bienes, porque la capacidad jurídica no depende de la orientación ni tampoco de la preferencia sexual.

Los movimientos de liberación femenina promueven el respeto de las libertades de las mujeres, y eso es respetable (p. e., la libertad de abortar o de tomar anticonceptivos; Gibbs, 2010, pp. 32-39). No obstante, ¿qué sucede cuando esas libertades tienen repercusión 
en la salud de la mujer, o en la violencia intrafamiliar, o en el maltrato infantil?

En conclusión, los responsables de las crisis afectivas de los infantes y los adolescentes son las personas que no son capaces de asumir el rol paterno ni tampoco el materno, y que no respetan los derechos superiores de los niños; aquellos que propician y auspician las guerras, porque terminan destruyendo las familias nucleares y los lazos afectivos de sus hijos. Es impresionante observar cómo juristas, periodistas, fiscales y jueces, en los debates, analizan las historias clínicas o hacen diagnósticos a la luz del DSM-V sin tener la competencia profesional (Aguilar, 2009).

Finalmente, si las autoridades piensan poner multas a los heterosexuales que discriminan a las personas diversas con fundamento en el artículo 134-A de la Ley 599 de 2000, me pregunto: ¿también colocarán multas a los que no toleran las mujeres islámicas que van a llegar a Colombia, o a los servidores públicos (fiscales, forenses y oficiales) que les hacen bullying a los hombres heterosexuales que son víctimas de algún delito?

\section{REFERENCIAS}

Acevedo, A. (2005). Casos y cosas. La realidad de los niños y jóvenes de hoy. Norma

Aguilar, R. (2009). Las pruebas psicológicas como instrumento para el diagnóstico de la personalidad. V. gr. El psicodiagnóstico de Rorschach y el cuestionario multifásico de la personalidad. Revista Universitas Canonica, 26(42), 27-42.

Alarcón, L. E. (2005). Canon 1095 e incapacidades psíquicas (tesis doctoral). Pontificia Universidad Javeriana, Bogotá.

Aquino, T. (2001). Suma teológica. BAC DVD.

Aristóteles (2000). La política. Alianza.

Barlow, D. y Durán, M. (2001). Psicología anormal: un enfoque integral. Ciudad de México: Itemex.

Barreda, N. (2001). La homosexualidad a la luz de la genética. https://www.bioeticaweb.com/la-homosexualidad-a-la-luz-de-la-genactica-dr-n-jouve-de-la-barreda/

Bieber, T., Dain, H., Dince, P., Drellich, M., Grand, H., Gundlach, R., Kremer, M., Rifkin, A. y Wilbur, C. (1988). Homosexuality: A psychoanalytic study. Londres: Aronson.

Brigham, J. (1984). Las libertades civiles y la democracia estadounidense. Gernika.

Burke, C. (1998). Sentencia (Homosexualidad). Rota Romana.

Cahill, L. (2012, 1 de octubre). His Brain, Her Brain. https://www.scientificamerican.com/article/his-brain-herbrain-2012-10-23/

Congreso de la República de Colombia (1991). Constitución Política de Colombia. https://www.ramajudicial.gov. co/documents/10228/1547471/CONSTITUCION-Interiores.pdf

Corte Suprema de Justicia. (2016, 24 de octubre). Exp. Sp 15269, Sala de Casación Penal. (Fernando Alberto Castro Caballero, Magistrado Ponente).

Departamento Administrativo Nacional de Estadística. (DANE). (2020). Estadísticas vitales: defunciones no fetales por grupo etario. https://www.dane.gov.co/index.php/estadisticas-por-tema/salud/nacimientos-y-defunciones/defunciones-no-fetales/defunciones-no-fetales-2020

Discovery Communications. (2005). Embarazo e infancia [DVD].

Elster, J. (1999). Juicios salomónicos. Gedisa.

Epstein, R. (2007). Mente y cerebro. American Scientific, 23, 54-60. 
Escobar, J. y Uribe, M. (2014). Avances en psiquiatría desde un modelo Biopsicosocial. Bogotá: Universidad de los Andes.

Fierro, M. (2014). Avances en psiquiatría desde un modelo biopsicosocial. Universidad de los Andes.

Gibbs, N. (2010). Love sex, freedom and paradox of the pill. Times, 175(17).

Hernández Bayona, G. (2013). Fundamentos de psiquiatría clínica: Niños, adolescentes y adultos. Revista Colombiana de Psiquiatría, 31(1), 73-74.

Kerbikov, O. V., Oseretzki, N. I., Popov, E. A. y Sneshneski, A. V. (1976). Manual de Psiquiatría. Editorial Pueblo y Educación.

Kolb, L. (1976). Psiquiatría clínica moderna. La Prensa Médica Mexicana.

Langman, I. (2004). Embriología médica. Editorial Médica Panamericana.

Lawrence, D. (1999). America: The Politics of Diversity (1a ed.). Westmont College West/Wadsworth \& International Thomson Publishing Company.

Lipsitz, L. y Speak, D. (1993). American democracy. St. Martin's Press.

Morgan, L. (1972). La sociedad primitiva. Universidad Nacional de Colombia.

Motta, M. C. (2005). Historia clínica n. 51812802 (Informe Anamopatológico LLETZ).

Parker Pope, T. (2007). Discusiones maritales se toman a pecho. The New York Times.

Stella, A. (1997). Interpretaciones rotales del dato psicopatológico a la luz del canon 1095 del cIc. Revista Universitas Canonica, 17(30), 73-99.

Tobin, W. J. (1964). Homosexuality and Marriage. Catholic Book

Tribunal Eclesiástico Regional de Bogotá. (2014). Causa de nulidad matrimonial de un oficial en Leticia, protocolo de prueba pericial n.174/14. Tribunal Eclesiástico Regional de Bogotá.

Uribe Uribe, V. (2001). El prodigio de la evolución del simio ancestral al hombre moderno. Cristina Uribe Editores.

Van Den Aardweg, G. J. M. (2005). Homosexualidad y esperanza: terapia y curación en la experiencia de un psicólogo. Eunsa.

Vásquez Rengifo. (2014). Informe Doppler Testicular en Bidestación. Prueba pericial expediente de Tribunal Eclesiástico de Bogotá. Tribunal Eclesiástico Regional de Bogotá.

West, R. (2000). Género y teoría del derecho. Universidad de los Andes e Instituto Pensar. 


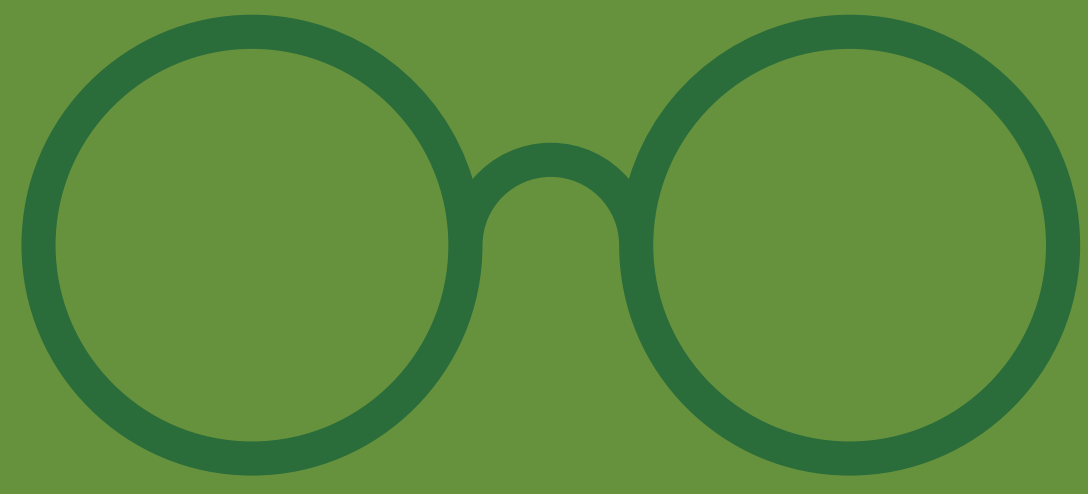

